\title{
ARBORESCENT LYCOPSID PRODUCTIVITY AND LIFESPAN: CONSTRAINING THE POSSIBILITIES
}

\author{
C. Kevin Boyce* \\ Department of Geological Sciences, Stanford University, Stanford, CA, USA. \\ *Author for correspondence: ckboyce@stanford.edu \\ William A. DiMichele \\ Department of Paleobiology, NMNH Smithsonian Institution, Washington, DC, USA.
}

\begin{abstract}
One of the most enigmatic components of early terrestrial vegetation was the arborescent lycopsids. Because of the sheer abundance of their biomass in many wetland environments of the Late Paleozoic, they may have been an important variable in the global carbon cycle and climate. However, their unusual structure has invited extraordinary interpretations regarding their biology. One idea that has persisted in the literature for over forty years is that these trees had extremely short lifespans, on the order of ten years. Such an accelerated lifecycle would require growth rates twenty times higher than modern angiosperm trees (and at least 60 times higher than modern lycopsids). Here, we evaluate the morphology and anatomy of lycopsid trees - including aerenchyma, phloem, leaf base distributions, leaf structure, rootlet anatomy, and the demography of the preserved fossils - with comparison to modern plants with some similarity of overall form, most notably the palms. The environmental context of lycopsid trees also is considered in the light of the vegetation of modern water-saturated substrates. It is concluded that such rapid growth would violate all known physiological mechanisms. One hypothetical mechanism that had been proposed to provide for increased carbon fixation, a unique photosynthetic pathway, could not have been viable in these plants and there is no accounting for the increases in nitrogen and phosphorous uptake that would be necessary to sustain enormous rates of carbon fixation. Of the various aspects of lycopsid anatomy and ecology that might militate against this conclusion that productivity was not high, no line of evidence requires a uniquely rapid growth rate for the arborescent lycopsids and several lines of evidence seem to prohibit it. Thus, we conclude that the lifespans of arborescent lycopsids most likely were measured in centuries rather than years. These trees should not be expected to have been unique outliers with physiological function completely distinct from all other tracheophytes. Furthermore, they require, no special consideration in the evaluation of Paleozoic biogeochemical cycling. Finally, the conclusion that lycopsid lifespans were an order of magnitude longer than previous expectations invites reconsideration of many other aspects of their ontogeny, physiology, and structure.
\end{abstract}

\section{Keywords}

Carboniferous; Lepidodendron; Lepidophloios; Oldest palm; Photosynthesis; Sigillaria; Stigmaria. 


\section{Highlights}

- 10-15 year lifespans for tree lycopsids repeatedly suggested in previous literature

- No aspect of structure, environment, or demography requires a rapid lifecycle

- No known mechanism could satisfy the extraordinarily high productivity requirements

- Fossil form and modern comparisons consistent with several hundred year lifespan

- Tree lycopsids were not outliers for productivity, climate or biogeochemical impact 


\section{1. Introduction}

2 The largest and most significant evolutionary radiations into new environments or

3 ecologies often have involved a rapid evolutionary turnover whereby the taxa dominant early in

4 the radiation are replaced by a different, more persistent association of taxa. For example, such a

5 pattern is repeated with the Cambrian fauna among marine invertebrates (Sepkoski, 1981),

6 Paleozoic fish and tetrapods (Benton, 1998), and Paleocene mammals (Alroy, 1999) and is also

7 seen in the earliest Silurian through Carboniferous vascular plants (Knoll, 1986; Niklas et al.,

8 1985). This limited evolutionary continuity with later, better-known biotas can complicate

9 dissection of the biology and ecology of the extinct lineages involved in these initial radiations.

10 One of the last and most morphologically complex examples during the early history of vascular

11 plants was the arborescent lycopsids, often segregated from the Isoetales as the

12 "Lepidodendrales" (DiMichele and Bateman, 1996). This group appeared in the Carboniferous

13 and reached its maximal diversity in Pennsylvanian-age wetlands. The unusual morphology and

14 anatomy of the arborescent lycopsids has invited speculation regarding many aspects of their

15 biology that extends beyond the bounds of what has been documented in living plants. Here, the

16 focus will be on evaluating suggestions of a highly accelerated lifecycle (Bateman, 1994;

17 Bierhorst, 1971; Phillips and DiMichele, 1992).

18 Different taxa among the arborescent lycopsids varied from 10 to 50 meters in maximum

19 height (Thomas and Watson, 1976; Wnuk, 1985, 1989) and from a decimeter to more than two

20 meters in trunk diameter (Thomas and Seyfulla, 2015; Walters, 1891) (Figure 1). They could be

21 polycarpic or monocarpic (DiMichele and Phillips, 1985). Some bore serially produced,

22 progressively abscised, lateral plagiotropic branches on their dominant orthotropic trunk

23 (DiMichele et al., 2013; Thomas et al., 2010; Wnuk, 1989); others had an orthotropic trunk that 
24 remained unbranched until a few distal dichotomies at the end of their ontogeny, associated with

25 the onset of reproduction (Andrews and Murdy, 1958; Bateman, 1994; DiMichele and Phillips,

26 1985; Eggert, 1961; Opluštil, 2010). All taxa tended to have a relatively small amount of

27 secondary xylem that was highly efficient in water conduction (Cichan, 1986) but played little

28 role in stem support (Figure 2). Instead, thick, peripheral secondary cortex, or periderm

29 (Williamson, 1872) of possibly water-resistant chemical composition (Boyce et al., 2010a;

30 Collinson et al., 1994) provided the structural support (Speck, 1994). None are known to have

31 had secondary phloem (Cichan, 1985; Eggert and Kanemoto, 1977). Leaves were linear and

32 varied among taxa, from small awl-shaped forms in plants such as Paralycopodites and

33 Bothrodendron (DiMichele, 1980; Thomas et al., 2010), to narrow, elongate forms a meter or

34 more in length borne proximally on the main trunk in most of the Lepidodendraceae and

35 Sigillariaceae (Graham, 1935; Kosanke, 1979; Rex, 1983). Leaves had few stomata and were

36 weakly vascularized. Some were anatomically simple while others had extensive sclerenchyma.

37 Leaves were closely packed on the stem and their abscission left persistent, taxonomically

38 distinctive leaf bases (Figure 2B) that were diamond, lozenge, or hexagonally shaped (Bateman

39 et al., 1992), although these leaf bases could be sloughed off in the largest/oldest stems of some

40 species, leaving an exposed surface of periderm or other cortical tissues at varying levels

41 (Bateman et al., 1992; Gensel and Pigg, 2010; Opluštil, 2010; Thomas, 1970; Wnuk, 1985). The

42 rooting systems of these plants, referred to as Stigmaria, were distinctly bipartite (Figure 2C),

43 consisting of dichotomous major axes on which were borne helically arranged lateral appendages

44 or "rootlets" (Eggert, 1972; Frankenberg and Eggert, 1969). At least in some cases, the rootlets

45 were produced by a ring meristem located behind the immediate apex of the main axis

46 (Rothwell, 1984). Because of this appendicular relationship to the main axis, the surficial rootlet 
47 attachment points on adpressed or cast specimens, and leaf-like rootlet anatomy (Stewart, 1947;

48 Williamson, 1887), rootlets and their parent axes frequently have been thought of in a manner

49 paralleling —or directly homologous to — leaves on the stem. The entire root system was

50 aerenchymatous (Figure 3A). In the main axes, the pith region of the vascular core was either

51 parenchymatous or hollow. In addition, the middle cortical region of the main axis was

52 composed of thin-walled tissue that either broke down during the life of the plant or shortly after

53 death (Figure 3A). Cortical airspaces were continuous with those of the leaf. The cortical region

54 of rootlets also was largely occupied by an air cavity, although rootlet and main-axis air cavities

55 were not directly connected due to a complex pad of sclerenchyma and parenchyma, sometimes

56 supplemented by secondary cortex/periderm (Stewart, 1947).

$57 \quad$ These trees could be so abundant in their environments as to represent a volumetric

58 majority of the biomass in many wetland ecosystems (Calder et al., 2006), but especially

59 peat/coal forming habitats (Phillips et al., 1985), particularly in the Carboniferous, a time when

60 more coal was deposited than at any other point in Earth history (Berner, 2003; Berner and

61 Canfield, 1989). Because of this abundance, understanding of their biology could appreciably

62 impact understanding of coal accumulation, the carbon cycle, sedimentary processes, and

63 perhaps even climate (Berner, 2004; Boyce et al., 2010a; Cleal and Thomas, 2005; Collinson and

64 Scott, 1987; Collinson et al., 1994; Davies and Gibling, 2011; Davies et al., 2011; Gibling and

65 Davies, 2012). This abundance has left us with a rich tree-lycopsid fossil record; however, that

66 record indicates a complicated and unusual biology that is not easily resolved and that possesses

67 no modern equivalents (though comparison to modern Isoetes may be useful for some attributes,

68 such as rootlet development). 
Estimates of the lifespans of these trees serve as examples of the complex ambiguity that

70 surrounds them. Lifespans of the large tree forms have been estimated to be extremely short -10

71 to 15 years (Phillips and DiMichele, 1992), if not even less (Bierhorst, 1971). Such fast

72 lifecycles, however, would impose extreme constraints upon other aspects of the biology of these

73 large trees. Here, we explore the viability of these estimates and consider other independent

74 lines of evidence that might inform upon the lifespans and growth rates of the arborescent

75 lycopsids.

\section{Original argument for a short lifespan}

The expectation that the arborescent lycopsid life cycle must have been unusually fast

80 ultimately appears to come, albeit indirectly, from the observation that there are almost no small

81 or intermediate sized individuals linking known tiny embryos (Phillips, 1979; Stubblefield and

82 Rothwell, 1981) with the widely known and reported large trees (e.g., Phillips and DiMichele,

83 1992; Thomas and Watson, 1976; Thomas and Seyfullah, 2015; Walters, 1891). From this

84 observation, it was argued both directly and indirectly that an absence of small individuals

85 indicates rapid growth, high productivity, and an accelerated life cycle (Bierhorst, 1971); a 10 to

8615 year lifespan (Phillips and DiMichele, 1992) was presented as a general illustration, rather

87 than as a firm quantitative estimate. [Other lines of argument that were considered in formulating

88 this estimate are considered in later sections: $4.2,4.3,4.4$.

89 The empirical lack of growth stages between miniscule embryonic and gigantic mature

90 phases of lycopsid trees (Figure 4) need not reflect rapid growth, however. For example, such an

91 observation may simply be a consequence of demography: local disturbance history, 
92 discrepancies between juvenile and adult mortality rates and reproduction/recruitment history

93 will strongly affect the age structure of any given population. Such factors even may produce

94 different age structures for different populations of the same species, as highly evident in human

95 populations. Even if any demographic issues are put aside and two species are considered that do

96 have profoundly different lifespans, then that would still provide no clear expectation of which

97 species should involve more mature individuals; it would not be the overall length of the

98 lifecycle that matters, but the proportion of the lifecycle spent as a juvenile. Thus, even if

99 Lepidodendron were a "normal" tree in every way, aside from possessing a 10 year lifecycle,

100 then still presumably the first year would have been as a recognizable sapling: yet $10 \%$ of the

101 trees are not juveniles, as would be expected under such a model. A rapid lifecycle, therefore,

102 would not resolve the problems of lycopsid biology. This does not require that the intuition of a

103 rapid lifespan is incorrect, only that the lifespan of arborescent lycopsids cannot be constrained

104 by the size distributions of fossils.

105

106

107 3. Can the productivity requirements of a short lifespan be satisfied?

108 Cleal \& Thomas (2005) generated per tree and per hectare estimates of the total carbon

109 budget of a Carboniferous swamp forest by combining volume calculations for an average

110 lycopsid tree with empirical measures of tissue carbon densities (Baker and DiMichele, 1997) of

111 the periderm and wood expected to represent the greatest proportion of tree carbon allocation. A

112 ten-year lifespan was then assumed in order to calculate annual productivity from that total

113 carbon content. The productivity value resulting from this calculation is high, almost 20 times

114 higher than modern angiosperm-dominated tropical rainforests and almost two orders of 
115 magnitude higher than actual living lycopsids (Brodribb et al., 2007). This productivity estimate

116 was then used to calculate that the waxing and waning of forest area occupied by such fast

117 growing trees would have had a 2-5 ppm/year impact on atmospheric $\mathrm{CO}_{2}-$ an impact as large as

118 that of modern anthropogenic forcing (Sabine et al., 2004). Such an extraordinarily high

119 productivity estimate might be taken as a persuasive argument that the lifespan of these trees

120 must have been considerably longer than ten years. Tree sizes are relatively well known. Tissue

121 proportions are more speculative, but the carbon content is relatively uniform across the relevant

122 tissue types - wood and periderm differed by only $20 \%$ and no sampled tissue differed from

123 wood by more than 50\% (Baker and DiMichele, 1997). Thus, changing the assumed proportions

124 of lycopsid tissues could accommodate no more than a 50\% decrease in productivity, not a

$1252000 \%$ reduction. The remaining variable in the productivity calculation is tree lifespan. Rather

126 than ten years, a lifespan of hundreds of years would be needed if productivity requirements

127 were to be brought down to a level comparable to even the most productive of living plants.

128 The short-lifespan interpretation, based on the above reasoning, would require a plausible

129 mechanism for greatly elevated productivity. Productivity potential should increase when

130 atmospheric $\mathrm{CO}_{2}$ is high and/or $\mathrm{O}_{2}$ is low (Beerling and Berner, 2000; Boyce and Zwieniecki,

131 2012), however Carboniferous $\mathrm{CO}_{2}$ concentrations are thought to be as low as they are now

132 (Beerling et al., 2002; Berner, 2006; Berner and Kothavala, 2001; McElwain and Chaloner,

133 1995; Royer et al., 2004) and $\mathrm{O}_{2}$ levels may have been higher (Beerling and Berner, 2000;

134 Beerling et al., 2002; Berner, 2006; Glasspool and Scott, 2010) suggesting that Carboniferous

135 productivity should have been comparable to modern levels or lower, not higher. Furthermore,

136 even the most favorable atmospheric compositions are not expected to result in more than a

137 factor of two or three increase in productivity over modern maximum levels (Beerling and 
138 Woodward, 1997; Brodribb and Feild, 2010; Franks and Beerling, 2009) and even that more

139 modest degree of $\mathrm{CO}_{2}$ fertilization may be limited largely to the angiosperms (Boyce and

140 Zwieniecki, 2012). An increase in growth and assimilation rates by a factor of twenty or more

141 would require a unique mechanism outside of any known physiological response common to

142 other plants.

143 A mechanism for increasing primary production in arborescent lycopsids has recently

144 been suggested: the scavenging of $\mathrm{CO}_{2}$ from decay processes in the organic-rich substrates of

145 these trees via a network of internal gas-filled channels allowing $\mathrm{CO}_{2}$ absorbed by the rooting

146 structures to diffuse up to the leaves (Green, 2010). This suggestion extrapolates from the

147 demonstration of the build up of $\mathrm{CO}_{2}$ in internal spaces during dark periods in aquatic and semi-

148 aquatic species of the small living lycopsid Isoetes (Keeley, 1987, 1998), some species of which

149 have no stomata and no visible means of $\mathrm{CO}_{2}$ absorption from the atmosphere. However, as

150 important as diffusion is at the micron to mm-scale, such as within a cell or from stomata to

151 mesophyll within a leaf, diffusion could not operate effectively over the forty or fifty meters of a

152 lycopsid tree from the rootlets through the Stigmaria rooting system and aerial trunk up to the

153 leaves. In the most generous of scenarios, one may assume that $50 \%$ of the cross sectional area

154 of the trunk is dedicated to airspace for diffusion, that a continuous airspace existed between the

155 rooting system spaces and the shoot (thus ignoring the tissue barrier between stigmarian rootlets

156 and the main axis), and that there was a $\mathrm{CO}_{2}$ concentration gradient of $100,000 \mathrm{ppm}$ in rootlet

157 airspaces (Barber, 1961) diminishing to $100 \mathrm{ppm}$ in the leaf. Under these assumptions, and using

158 the most simplified and idealized equation for Fick's Law of Diffusion ${ }^{1}$, an estimate of

$1 \frac{m}{t}=-D S \frac{C_{1}-C_{2}}{x}$, where $m$ is mass, $t$ is time, $D$ is the diffusion coefficient, $S$ is the crosssectional area of the diffusion path, $C_{1}$ and $C_{2}$ are concentrations of source and sink, and $x$ is the path length. The use of this equation is an oversimplification intended only as an order-of- 
159 approximately $200 \mathrm{~g}$ of carbon would be made available to the leaves per year via diffusion.

160 Using the Cleal \& Thomas (2005) estimate of Lepidodendron carbon content, it would then take

161 more than 10,000 years to grow a tree. Any correction of the relevant parameters-less than

$16250 \%$ of the trunk dedicated to airspace, less extreme Stigmaria $\mathrm{CO}_{2}$ concentrations, less than

$163100 \%$ conversion to photosynthate of the $\mathrm{CO}_{2}$ reaching the leaves - should only serve to increase

164 that estimate of tree life span.

165

Convection through internal airspaces can be found among modern aquatic and wetland

166 plants, with mechanisms including the negative pressures generated by the Venturi effect as

167 external winds pass over the plant or the positive pressures generated by the humidification of

168 drier atmospheric air entering via the stomata (Armstrong and Armstrong, 2009; Armstrong et

169 al., 1992; Beckett et al., 1988; Raven, 2009; Vogel, 1994). In addition to stomata, however, the

170 tree lycopsids also possessed internal aerenchymatous channels through the periderm and leaves,

171 the so-called parichnos (Bertrand, 1891), generally presumed to be aerating strands (Hook et al.,

172 1972; Jeffrey and Wetmore, 1926). These strands ran internally from the middle cortex of the

173 stem through the leaves, and were exposed on the outer surface of the stem following leaf

174 abscission. In addition, in the Lepidodendraceae s.s. (DiMichele and Bateman, 1996), the

175 parichnos strands branched just before the point of leaf attachment to the leaf cushion, the lower

176 channels appearing as external parichnos openings immediately below the point of leaf

177 attachment (Figure 3B). Thus, the open connection to the exterior presented by the external

178 parichnos and by the post-abscission parichnos openings should have been compatible with

179 Venturi effects. This open connection, however, would have likely violated a key requirement of

magnitude illustration of the inefficiency of diffusion at larger spatial scales. More complex calculations would be unwarranted given the poor constraint of parameter values. For detailed discussion of diffusion in plants, see: Vogel, S., 2012. The life of a leaf. Chicago: University of Chicago Press. 
180 humidity-induced convection, that positive pressures generated as atmospheric air is humidified

181 in the photosynthetic tissues not be lost to immediate backflow to the atmosphere (Armstrong

182 and Armstrong, 2009).

183 Despite the potential that parichnos offer for connection of the plant's interior to the

184 atmosphere, any form of convection will ultimately depend on a through-flow of gases (Beckett

185 et al., 1988), of which the arborescent lycopsids may not have been capable. In those modern

186 plants where convection has been demonstrated, points of gas entry and egress are both required.

187 This may entail flow in and out through different aerial stems or leaves, or even different areas of

188 the same leaf (Große, 1996), but in no case does it resemble the closed circulatory system of an

189 animal. For example, convective flow through Equisetum involves the venting of humidity-

190 induced pressure developed in photosynthetically active axes through the broken off stubble of

191 older axes, thereby ventilating the rhizome connecting successive aerial axes, but no convection

192 is seen in those Equisetum species where their aerenchyma architecture does not provide for

193 through-flow of air currents (Armstrong and Armstrong, 2009) - the mere presence of air

194 channels in all Equisetum does not mean that all experience convective airflow. Similarly,

195 airflow may well have been possible out of (or in to) the parichnos of the distal parts of the

196 arborescent-lycopsid aerial axis, and - if the disintegration of the middle cortex of the axes was

197 during the lifetime of the plant — a continuous air space may have existed through the stem and

198 rooting systems. Stigmaria, however, appears to have been a dead end with no capacity to

199 provide the second vent needed for convective airflow. Stigmarian rootlets would be the obvious

200 candidate capable of reaching to and venting to the atmosphere even if the stigmarian axes were

201 submerged. However, a pad of tissue at the base of each rootlet, the so-called rootlet cushion,

202 separated the rootlet airspace from that of the parent axis (Stewart, 1947), thereby preventing 
203 convective flow. Convective internal airflow would be required to bypass the inefficiencies of

204 diffusion in order to have any $\mathrm{CO}_{2}$ available in the substrate reach the leaves, but arborescent

205 lycopsid anatomy is not consistent with that convection.

206 More problematic, regardless of how the $\mathrm{CO}_{2}$ is transported once within the body of the

207 plant, is the rate of $\mathrm{CO}_{2}$ diffusion in water, which would mediate any transfer of $\mathrm{CO}_{2}$ from the

208 substrate into the root system. Diffusion of $\mathrm{CO}_{2}$ is $10^{4}$ slower in water than in air (Vogel, 2012);

209 all other things being equal, the last $3 \mathrm{~mm}$ of aqueous diffusion of $\mathrm{CO}_{2}$ through the rootlet tissue

210 into the plant would be as slow as $30 \mathrm{~m}$ of diffusion through internal air channels within the

211 plant. [As with convection, the large total surface area of each tree's stigmarian rootlets might

212 have mitigated some of the challenges of that aqueous diffusion to the internal airspaces, but the

213 pad of tissue separating rootlet and axial airspaces (Stewart 1947) would instead require an

214 additional barrier of aqueous diffusion through that tissue for any transport between the two

215 airspaces.] Thus, even if active convection through the air channels were available, this would

216 not alleviate the difficulties attendant on $\mathrm{CO}_{2}$ entry to the aerenchyma network in the first place.

217 It is notable that this concern does not apply in the opposite direction: the widespread occurrence

218 of aerenchyma in wetland plants is more typically thought to facilitate movement of $\mathrm{O}_{2}$ down

219 from the atmosphere rather than $\mathrm{CO}_{2}$ up from the waterlogged substrate, so that the source does

220 not involve an aqueous diffusive step.

221 Airspaces could plausibly have been involved in the local salvaging of metabolic $\mathrm{CO}_{2}$

222 from the respiration of adjacent tissues within the plant (Raven, 1970). However, low net

223 productivity would be indicated were such recycling to have provided a substantial fraction of

224 the overall $\mathrm{CO}_{2}$ used in photosynthesis. Consistent with living plants where the scavenging of

225 metabolic $\mathrm{CO}_{2}$ is important, such as CAM plants (Griffiths et al., 1989), the implication would 
226 be that the arborescent lycopsids were like other slow growing tolerators of stress, not exceptions

227 to these general physiological rules. If any function ultimately can be assigned to parichnos, it

228 may have to be something of such a limited extent as metabolic recycling. This is suggested by

229 the anatomy of several phylogenetically basal groups of the arborescent lycopsids (Bateman et

230 al., 1992) that had parichnos systems but had neither leaf abscission nor external (infrafoliar)

231 parichnos. Their parichnos system therefore was strictly internal. Thus, the plesiomorphic

232 function of the parichnos system - whatever it may have been - appears not to have been

233 associated with exposure of the internal aerenchyma channels to the external environment.

234 All of the above only address the need for a twenty-fold increase in $\mathrm{CO}_{2}$ assimilation

235 rates in order for a short lifespan to be a possibility for arborescent lycopsids, but no organism is

236 made only of carbon. If a hypothetical mechanism for vastly increased carbon fixation were

237 available, it would not address the need for corresponding increases in nitrogen and phosphorous

238 uptake, both often being limiting in wetland habitats (Bowden, 1987; Day, 1982; Mitsch et al.,

239 1979). In part, wetland environments often can be stressful and unproductive for vascular plants

240 specifically because of the limited availability of these nutrients to root systems growing in

241 waterlogged, anoxic substrates, a problem exacerbated on peat substrates (Schlesinger, 1978) and

242 in still water and ombrotrophic habitats (Brinson et al., 1980; Mitsch et al., 1979; Page et al.,

243 1999). The absorptive organs of arborescent lycopsids were rootlets that were a few millimeters

244 to a centimeter in thickness and lacked root hairs entirely (Figure 2C, 3A). Some potential for

245 fungal symbiosis has recently been demonstrated (Krings et al., 2011), but appears to have been

246 limited to middle cortical tissues lost to airspace formation early in rootlet ontogeny. As a result,

247 for a rootlet that is $6 \mathrm{~mm}$ in overall diameter with a $4 \mathrm{~mm}$-wide central air cavity, the surface

248 area for absorption relative to overall volume would be at more than a 300-times disadvantage 
249 relative to a $10 \mu$-wide root hair and more than a 1000 -times disadvantage relative to a $3 \mu$-wide

250 mycorrhizal hypha. To be sure, root hairs and mycorrhizal associations are also less prevalent-

251 although not absent — in modern wetland plants (Khan, 2004; Romberger et al., 1993; Smith and

252 Read, 1997), but the anatomy of the arborescent lycopsids is consistent with this limitation rather

253 than presenting any obvious anatomical solution. Thus, at least as much as is the case for other

254 stress-tolerant vascular plants living in nutrient-poor wetland environments, carbon fixation

255 likely would have been secondary to other, much larger nutrient limitations on growth.

\section{4. Other potential constraints on lifespan}

258 No known physiological mechanisms could approach the productivity rates necessary for 259 arborescent lycopsids to have had a rapid lifecycle. This conclusion is supported all the more so 260 by a low- $\mathrm{CO}_{2} /$ high- $\mathrm{O}_{2}$ atmospheric composition that would have been unfavorable for carbon 261 fixation and by stagnant, waterlogged substrates that would have limited phosphorous and 262 nitrogen uptake. This argument is deemed adequate to reject rapid growth in the arborescent 263 lycopsids. What remains to be seen is whether any aspects of lycopsid structure might militate 264 against that conclusion. Do any aspects of their form, ecology, or environmental context require 265 reviving the possibility of very rapid growth or are they consistent with being slow growing, 266 stress tolerant plants?

$268 \quad 4.1$ Leaf base crowding

269 A 10 to 15 year lifespan for arborescent lycopsids would require 3 to $4 \mathrm{~m}$ of growth per

270 year in the largest taxa. Where such rapid rates of extension do exist, they are typically

271 associated with climbers freed from the need to provide their own structural support. Greater 
272 than $2 \mathrm{~m}$ of growth per year is known among living self-supporting plants, but rapid growth is

273 typically accommodated by extensive internode elongation, e.g. bamboo, the bolting

274 reproductive axes of rosette plants, the long shoots of Ginkgo relative to the short shoots. For

275 example, the presence or absence of internode elongation is recognized to be of central

276 developmental and ecological importance within the palms: rattan palms may grow $6 \mathrm{~m}$ in a year

277 with that growth accommodated by only 3 or 4 fronds separated by internodes up to $2 \mathrm{~m}$ long,

278 whereas slower growing palms without internode elongation may take 80 years to achieve the

279 same stem growth (Henderson, 2002). Overall, a sampling of palms with internodes yields an

280 average of $40 \mathrm{~cm} /$ year of stem growth, whereas those without internodes average only 10

$281 \mathrm{~cm} /$ year (Henderson, 2002). Most arborescent lycopsids have no elongation at all between their

282 persistent leaf bases. The one exception would be some forms of Sigillaria, which have zones of

283 modest cm-scale elongation between leaf bases alternating with areas without elongation

284 (Thomas, 1972). Although not providing any quantitative constraints on growth rates, the little to

285 no separation of leaf bases in most arborescent lycopsids, including the largest forms (Figure

286 2B), is qualitatively more consistent with slow stem growth, e.g. rosette plants, cycads, the short

287 shoots of Ginkgo. The external morphology of arborescent lycopsids does not conform to what

288 could be expected of plants with extremely rapid stem growth.

$290 \quad 4.2$ Absence of secondary phloem

291 Phloem cells are typically short-lived, lasting only a few years (Tomlinson, 2006). The

292 lack of secondary phloem — as in the arborescent lycopsids — might be expected to limit the

293 longevity of any single stemmed tree. Since the sieve elements must survive and remain

294 functional over the entire lifetime of the plant, their inevitable failure might be expected to put a 
295 firm upper limit on lifespan. Palms, however, lack secondary growth, but provide examples of

296 strikingly long-lived primary tissues nonetheless. Age is difficult to assess in palms without

297 wood rings to count and where the continuous metabolic activity of living tissues would

298 complicate any attempt to use ${ }^{14} \mathrm{C}$ dating, but historical documentation of individual trees does

299 exist. Whereas most trees may only live for several decades (Henderson, 2002), that does not

300 present an upper limit. Although some of the oldest known palms (e.g. the Chamaerops humilis

301 specimen, known as the "Goethe Palm" planted in 1568 in Padua) are multi-stemmed so that no

302 individual stem lives very long, the documented lifespans of single-stemmed species can

303 approach or surpass 200 years: a specimen of Jubaea chilensis, growing in a Kew Gardens

304 greenhouse was planted in 1843 and a specimen of Elaeis guineensis at Bogor Botanic Gardens

305 is slightly older (Tomlinson, 2006; Tomlinson and Huggett, 2012). Another long-lived single-

306 stemmed palm is documented here to have lived exposed in an urban street setting at the Palm

307 Tree Mosque in Capetown, South Africa. Already a substantial tree in 1840 and, presumably, at

308 the mosque's inception in 1807 (Toffa, 2004), this plant survived past 1988 (Figure 5). Beyond

309 the direct documentation of these long-lived individuals in cultivated environments,

310 extrapolations from leaf scars and frond lifespans (discussed further in Section 4.5, below)

311 suggest — albeit less directly — that individuals of some palm species may live more than 700

312 years in their natural environments (Uhl and Dransfield, 1987). Thus, palms demonstrate that

313 individual plant cells can live a remarkably long time — at least 200 years, presumably much

314 longer-indicating that the aging of these cells will not necessarily truncate potential lifespan

315 (Tomlinson, 2006).

316 Even if phloem were to impose some minor constraints on maximum lifespan in palms,

317 those constraints may not apply to arborescent lycopsids. The longevity of palm sieve tubes is 
318 all the more remarkable because they are enucleate, but living lycopsids including Lycopodium,

319 Selaginella, and Isoetes maintain degenerate nuclei in their sieve cells that may presumably

320 contribute to continued cell function (Burr and Evert, 1973; Kruatrachue and Evert, 1974;

321 Warmbrodt and Evert, 1974). Although the phloem of the arborescent lycopsids is almost never

322 preserved, their phylogenetic relationships suggest this characteristic of persistent phloem nuclei

323 may well have applied to them as well, perhaps making phloem longevity even less of a concern.

324 Furthermore, a lack of secondary phloem is thought to be a primary limitation preventing palms

325 from occupying environments prone to frost (Tomlinson, 2006), but some early tree lycopsids

326 may have lived in close proximity to the ice front of the Late Devonian glaciation recorded in

327 Appalachian basin strata of the Eastern United States (Brezinski et al., 2010; Brezinski et al.,

328 2009). As with certain New Zealand tree ferns known to grow in the immediate vicinity of

329 modern glaciers (Lindsay, 1868), a lack of secondary phloem may provide less of a constraint on

330 ecology and lifespan that often surmised.

331 A final consideration regarding the absence of secondary phloem in arborescent lycopsids

332 is the observation that even their primary phloem is generally quite restricted throughout the

333 body of the plant (Phillips and DiMichele, 1992). Arborescent lycopsids have either long,

334 deciduous leaves, or short, permanently retained leaves, and nearly all have sporophylls with

335 prominently leafy distal laminae. Given the limited amount of phloem (Figure 6A, B), most of

336 the photosynthate generated by leaves and sporophylls may have been used locally, either in

337 apical growth, periderm production, or in sporangia and spores, with only limited longer distance

338 transport. Such local use and limited translocation has parallels in other plants, where sepals, for

339 example, have been shown to contribute substantially to flower development (Bazzaz et al.,

340 1979). The leaf-like anatomy of stigmarian rootlets has even led to the suggestion that the 
341 rooting systems of these plants may have been self-sustaining, with upwardly directed rootlets

342 being emergent from the substrate and functional as photosynthetic appendages (Phillips and

343 DiMichele, 1992). The trunk itself connecting proximal rooting system and the distal growing

344 apex may have had relatively limited metabolic demands: wood was certainly dead at maturity,

345 periderm also may have been (although this is not certain and may well have been variable given

346 the variability of periderm structure: (Bateman et al., 1992; Eggert, 1961; Gensel and Pigg,

347 2010), and much of the intervening cortex appears to have been subject to degradation and

348 aerenchyma formation. To the extent that these inferences are persuasive, the limited carrying

349 capacity of the phloem system may have constrained growth rates throughout the plant but

350 would not constrain longevity.

$352 \quad 4.3$ Survival until reproduction in monocarpic taxa

A determinate, monocarpic life cycle, characteristic of several major lycopsid taxa

354 (DiMichele and Phillips, 1985; Phillips, 1979; Phillips and DiMichele, 1992) is one that entails

355 considerable risk; pushing reproduction to terminal phases of a long life raises the possibility of

356 pre-reproductive death; various lines of evidence (Gastaldo, 1986) suggest that lycopsid trees

357 often grew in disturbed settings where blow downs, fires, and intense floods (DiMichele et al.,

358 2009) might preclude completion of a long life cycle. Yet, whereas prostrate lycopsid trunks are

359 known in abundance, immature crowns or unbranched trunks with apices (Figure 7A) are

360 essentially unknown with very few exceptions (Goldenberg, 1855; Kosanke, 1979). This

361 absence could be inferred to suggest that nearly all trees completed their life cycles prior to death

362 (Bateman, 1994). Thus, the success of monocarpy in lycopsid trees has also been taken as

363 evidence of a highly accelerated lifecycle (Bierhorst, 1971). However, the trunks of the 
364 monocarpic taxa were unbranched until the reproductive phase at the end of their lifecycle

365 (Figure 7B, C). Thus, these trees would have presented, little profile to the wind (Niklas, 1998),

366 and would have had low risk of blow-down prior to formation of the branched crown.

367 Furthermore, it is the leaves of a tree in aggregate that provide most of the drag that can result in 368 windfalls during storms (Vogel, 1994), and leaves abscised at some point in the larger

369 monocarpic lycopsid taxa. Indeed, uprooted lycopsid trees are unknown to us from either the

370 literature or field observation, although this does not preclude that their trunks would have been

371 prone to fail and snap before wind speeds high enough to uproot them were reached (DiMichele

372 and DeMaris, 1987).

373 In any case, both monocarpic and polycarpic taxa existed and, if survival until

374 reproduction were a dominant selective agent, then the monocarpic taxa might be expected to be 375 smaller than the polycarpic taxa. In fact, the situation is considerably more complex. Polycarpic 376 trees come in both small (Figure 8A) and large (Figure 8C) growth forms, and appear to be 377 primitive/plesiomorphic among the overall tree lycopsid clade (Bateman et al., 1992; DiMichele 378 et al., 2013). Monocarpic tree taxa, in contrast, are derived evolutionarily (Bateman et al., 1992), 379 apparently reflecting developmentally mediated, heterochronic changes in the timing of 380 reproduction (Bateman, 1994). There also are a number of smaller isoetalean forms, up to several 381 meters in height, such as Chaloneria cormosa, a monocarpic form inferred to be derived on the 382 basis of phylogenetic analysis (Bateman et al. 1992) and on the stratigraphically earlier 383 occurrence of polycarpic Chaloneria periodica (DiMichele et al., 1979; Pigg and Rothwell, 384 1983). Thus, monocarpy may have been a derived developmental condition in various lycopsid 385 lineages. This does not appear to reflect an acceleration of growth rate and an early onset of 386 reproduction relative to polycarpic ancestral forms, but rather a delay in the onset of 
reproduction, pushing it into the period of crown formation, accompanied by the compression of

388 ancestral, multi-strobilus deciduous lateral branches (Figure 8B) to highly reduced branching

389 systems bearing single cones (Bateman, 1994; Bateman et al., 1991). Given that all the large

390 lycopsid trees appear to have undergone crown formation associated with growth termination,

391 regardless of their overall size, monocarpy, per se, does not appear to have been a crucial factor

392 limiting lycopsid lifespan.

\section{$394 \quad 4.4$ Paleoecology and sedimentology}

395 The environments in which in situ tree bases are preserved typically indicate rapid, and in

396 some instances catastrophic, burial of large stands of trees, the abundance and similar size of

397 which may indicate monotypic lycopsid dominance and even cohort establishment (DiMichele

398 and Falcon-Lang, 2011; Thomas and Seyfulla, 2015). This could lead to the conclusion that

399 these plants were highly productive ecosystem dominants that lived primarily in settings prone to

400 sediment-laden floods or coastline progradation where rapid growth may have been required for

401 lifecycle completion. In fact, it should be considered that such fossilized forests are uncommon

402 and probably not representative of the habitats preferred by these species. Consider that the most

403 common occurrences of lycopsid aerial remains are in peat swamp (coal balls) and clastic-

404 swamp settings, floodplain environments, and even in carbonate muds, in all cases without being

405 attached to upright stems. This is prima facie demonstration that the lycopsid trees were

406 widespread and not confined, or even found most often, in environments conducive to rapid,

407 aperiodic flooding and sediment deposition. Indeed, there is no guarantee the trees of frequently

408 disturbed environments formed self-sustaining populations; they may have been dependent on

409 propagule dispersal from more stable environments where reproductive potential was not 
410 repeatedly truncated by disturbance. Furthermore, partial burial need not have been lethal

411 (DiMichele and Falcon-Lang, 2011). Finally, although some stands of fossil trees may appear to

412 have been lycopsid-dominated, this is the exception rather than the rule; most stands consist of

413 multiple species and genera, based on prostrate axes of such plants as tree ferns and

414 pteridosperms amidst the standing trunks of lycopsids ((DiMichele et al., 2007; Gastaldo et al.,

415 2004; Opluštil et al., 2009). In one exceptional case (Willard and Phillips, 1993), two trunks of

416 Psaronius and one of a calamitalean were found to extend from the underclay to the top of a >0.6

417 m thick mass of permineralized peat in the Late Pennsylvanian Friendsville coal of Illinois, USA.

418 Thus, if in situ lycopsid trunks are presumed to indicate productivity many times higher than

419 living plants, that uniquely high productivity must have applied across a broad swath of the

420 vascular plant phylogeny during the late Paleozoic. Where monotypic stands do exist, they

421 might be considered as likely to reflect high levels of environmental stress, and exclusion of

422 other taxa unable to handle the particular stresses of the environment, rather than high lycopsid

423 productivity. In all cases, highly elevated growth rates may not be inconsistent with

424 sedimentological evidence, but in no case is that answer a unique requirement. High growth

425 rates would at best be one potential explanation among several.

427 Direct measures of growth rates from fossil leaf characteristics?

428 In theory, fossil specimens with leaves in axial attachment can provide a rough estimate

429 of tree lifespan as long as leaf lifespan can be estimated: length of axis with leaves (meters)

430 divided by leaf lifespan (years) provides an estimate of axial growth rate that can then be

431 compared to the overall height of the tree in order to estimate the tree's age. Such an approach

432 has been used with a variety of living plants, such as palms, for which no tree rings are available, 
433 but leaf scars can be counted and leaf lifespan can be observed (Uhl and Dransfield, 1987).

434 However, in practice, fossils present a series of challenges not faced when using this method

435 with extant plants. The short, awl-like and permanently attached leaves of some arborescent

436 lycopsids, such as Paralycopodites (Figure 8A), do not allow for a determination of functional

437 leaf lifespan. In those arborescent taxa that do have leaf abscission, axes with attached leaves

438 (Chaloner and Meyer-Berthaud, 1983; Kosanke, 1979; Leary and Thomas, 1989; Rex, 1983;

439 Thomas, 1970) are typically too fragmentary to determine an accurate length of a leaf-bearing

440 stem segment. It does appear, however, that leaves covered at least a meter or so of trunk length

441 within the crown of the monocarpic Lepidodendron (Kosanke, 1979) (Figure 6C).

442 Research on the leaf economic spectrum (Reich et al., 1999; Wright et al., 2004; Wright

443 and Westoby, 2002) cannot provide a direct estimate of leaf lifespan in the tree lycopsids-

444 existing work has been focused on seed plants, specifically angiosperms - but can provide some

445 general expectations: long-lived leaves with low photosynthetic rates tend to be thick and well

446 defended via sclerenchyma or secondary chemistry, whereas short-lived leaves with high

447 photosynthetic rates tend to be thin. Thick leaves will tend to have lower maximum

448 photosynthetic rates because of the greater diffusive path lengths for $\mathrm{CO}_{2}$ from the stomata

449 through the mesophyll (Boyce et al., 2009; Brodribb et al., 2007; Zwieniecki and Boyce, 2014),

450 requiring longer leaf lifespans for equivalent productivity in comparison with thin, short-lived

451 leaves. Leaf laminae of the tree lycopsids are $1 \mathrm{~mm}$ or more in thickness. Such thick leaves

452 would correspond to leaf lifespans of at least several years among living angiosperms (Wright

453 and Westoby, 2002). For comparison, leaf lifespans among conifers range from less than six

454 months to more than forty years (Reich et al., 1995). Data for lycopsids are scarce, but even the

455 thin leaves of extant temperate species live for four to six years (Nauertz and Zasada, 1999), so 
456 the leaves of the main trunk in the lycopsid trees - more than $1 \mathrm{~mm}$ in thickness and up to a

457 meter in length (Andrews and Murdy, 1958; Kosanke, 1979) (Figure 6C)—would presumably

458 have functioned considerably longer. If a ten-year leaf lifespan is chosen for illustrative

459 purposes, then a meter of stem covered with living leaves would translate to a $10 \mathrm{~cm} / \mathrm{year}$ growth

460 rate and a $40 \mathrm{~m}$ tall lycopsid being 400 years old. All numbers involved in that calculation are

461 order of magnitude estimates and the resulting whole-tree lifespan estimate could easily be

462 pushed up to 800 years (e.g. if leaf lifespan were 20 years) or down to 200 years (e.g. if the distal

$4632 \mathrm{~m}$ of trunk bore living leaves). However, a tree lifespan of only one or a few decades would

464 not be consistent with the large sizes of the trees in conjunction with the long leaf lifespans

465 reflected by high leaf thicknesses and/or sclerenchymatous construction.

$467 \quad$ 5. Implications

\section{$468 \quad 5.1$ Productivity and lifespan}

469 No line of evidence requires a uniquely rapid growth rate for the arborescent lycopsids

470 and several lines of evidence appear to prohibit it. Of the various mechanisms that might be

471 entertained to explain elevated rates of carbon assimilation, none appear to be viable. No

472 mechanism has been proposed for the greatly increased rates of nitrogen and phosphorous

473 acquisition that would be needed to keep up with increased photosynthetic rates and no such

474 mechanism seems forthcoming. Rather than ten to fifteen years or less, lifespans were more

475 likely on the order of at least several decades for the smaller trees and a few hundred years for

476 the largest. A reasonable starting point might be the expectation that these plants were no more

477 productive than modern mesic angiosperm trees, leading to at least a 200 year lifespan for a

478 Lepidodendron of the dimensions considered by Cleal and Thomas (2005). That baseline 
479 expectation might increase to 800 years or more with allowances for the low productivity of

480 modern lycopsids or, more generally, the depressed productivity that can accompany permanent

481 substrate flooding (Armstrong et al., 1994; Kozlowski, 2002; Lopez and Kursar, 1999; Pezeshki,

482 2001; Talbot et al., 1987), although that baseline might be brought back down to approximately

483400 years with lower tissue densities than assumed by Cleal and Thomas (2005). The spacing of

484 leaf bases and likely leaf lifespans of lycopsid trees are consistent with these baseline

485 calculations.

486

487

488

\subsection{Ontogeny and architecture of arborescent lycopsids}

Of most direct relevance to paleobotany, the amount of fossil data regarding the

490 arborescent lycopsids is enormous (Taylor et al., 2009), but much of it is not easy to reconcile.

491 The suggestion of extraordinarily high productivity was an attempt to account for some of the

492 complexities of arborescent lycopsid biology, but recognizing the impossibility of a ten-year

493 lifespan invites reconsideration of those issues. A prime example is the original evidentiary

494 basis for suggesting a rapid lifespan: if the seeming absence of juvenile specimens is neutral

495 regarding the matter of lifespan, it nonetheless leaves us with the problem of the "missing"

496 juveniles, undergirded by thousands of person-years of examination of outcrops and mine

497 exposures, with eyes on tens of thousands of arborescent lycopsid specimens.

498 Why are trees that might be characterized as "juvenile" or "immature" so rare as to be

499 virtually unknown among the arborescent lycopsids? Several possibilities present themselves.

500 One explanation might be that the absence could be strictly taphonomic: either small trees lacked

501 the secondary tissues that gave large trees high preservation potential, or old, long-dead trunks 
502 remained intact so that the large trees end up overrepresented relative to little plants in any

503 sample, or both. However, although preservation biases are always a concern, they are unlikely

504 to explain fully an absence of clearly identifiable juveniles when even arborescent lycopsid

505 embryos are well known (Phillips, 1979). An alternative explanation would be simply that we

506 don't know how to recognize young trees. The expectation that young trees should be small

507 trees comes from an expectation of extensive secondary growth, i.e. the expectation of a sapling

508 stage. However, a sapling stage cannot be preserved if a sapling stage never existed. Large slabs

509 of intact, unseparated leaf bases indicate a large primary body and the preservation of non-

510 abscised leaves on large stems demonstrates that full trunk diameter was achieved close to the

511 apex. The only examples of which we know that illustrate such specimens are the engravings of

512 juvenile Sigillaria stems (Figure 7A) in Goldenberg (Goldenberg, 1855). Useful analogues to

513 consider may be the primary thickening meristems of palm and cycad taxa that establish their

514 full diameter immediately below the apex and do so early in ontogeny by the time the trunk

515 emerges from the substrate. Thus, large lycopsid stump casts (Thomas and Seyfulla, 2015) may

516 easily be assumed to have represented tall, mature trees, but a cast $0.8 \mathrm{~m}$ wide and $2 \mathrm{~m}$ tall may

517 only require that the tree was taller than $2 \mathrm{~m}$, not a full 30 or $40 \mathrm{~m}$.

518 The fossil record of in situ occurrences of arborescent lycopsid trees, including tree

519 stumps and prostrate trunks, (DiMichele and Falcon-Lang, 2011) is broadly consistent with the

520 possibility that large fossils need not represent mature trees. First, the most commonly preserved,

521 autochthonous remains of lycopsid trees are tree stump casts (Thomas and Seyfulla, 2015);

522 although the length of trunk associated with bases is variable, most specimens are truncated close

523 to the stem base. A complete buried sexually mature tree has not been reported, to our

524 knowledge, although fragmentary tree crowns preserved under nearly autochthonous conditions 
525 have been reported (e.g. Opluštil, 2010). Second, the great majority of prostrate trunks are

526 partial specimens without base or crown. Trunks exceeding $30 \mathrm{~m}$ in length are rarely reported in

527 the literature. Consequently, it cannot be ruled out that partially preserved tree bases and trunks

528 are juveniles, particularly in the case of monocarpic taxa (e.g. Lepidodendron, Lepidopholoios,

529 and perhaps Sublepidophloios). As an additional consideration, however, to our knowledge there

530 are no reports of prostrate trunks of those forms with deciduous lateral branches (e.g.,

531 Paralycopodites, Diaphorodendron, Synchysidendron, Bothrodendron) in which such branches

532 are preserved in attachment to the main stem (see Figure $8 \mathrm{~A}, \mathrm{C}$ for examples of such stems).

533 Thus, the problem persists: young plants of this polycarpic growth form should be highly

534 recognizable based on attached branches, yet there are no such specimens reported in the

535 literature, to our knowledge.

536 As a final consideration, we propose that it may be unrealistically optimistic to expect

537 juvenile trees to be well represented in the fossil record. Juveniles of Psaronius and Calamites

538 are also not known, or at least not recognized as such. There are exceptions (Beck, 1967), but

539 fossil juveniles are rare in general. Juveniles may represent a demographic bottleneck,

540 particularly in the stressful wetland environments that provide much of the fossil record.

541 Megaspore-bounded embryos may be abundant, adults may persist for long lifespans once

542 established, but few individuals at any one time may be in the transitory stage in between.

543 Saguaro cacti are a modern example of such population dynamics in a stress tolerant plant for

544 which a century may pass between successful recruitment years (Drezner, 2014). Leaves can

545 provide a final comparison: the number of Spiropteris croziers that have been described

546 (Bomfleur et al., 2011; Crookall, 1925; Diéguez and Meléndez, 2000; Kidston, 1884) is

547 vanishingly small when compared to the total number of fossil fern and pteridosperm leaves that 
548 have been observed. As with investigation of the evolution of leaf development (Boyce, 2008;

549 Boyce and Knoll, 2002; Sanders et al., 2007), the mature forms preserved as fossils may be a

550 better starting point for considering the ecology and structure of juvenile arborescent lycopsids

551 than the unpreserved (or unrecognized) juveniles themselves. The implications for classic

552 interpretations of arborescent lycopsid anatomy, ontogeny, and establishment (Andrews and

553 Murdy, 1958; Eggert, 1961) are the subject of continuing investigation.

\section{$555 \quad 5.3$ Geobiology and the physiology of fossil plants}

556 Plants are active participants in the creation of their environments, not just passive

557 recipients (Algeo and Scheckler, 1998; Boyce et al., 2010b; Davies and Gibling, 2013; Odling-

558 Smee et al., 2003; Scheffer and Carpenter, 2003). In any geobiological consideration, they

559 cannot be lumped as a single homogenous vegetation; the evolution of ecology, architecture, and

560 physiology matters on a lineage by lineage basis as has been demonstrated for extant ecosystems

561 (Prinzing, 2001; Webb et al., 2002; Wiens et al., 2010) and inferred even for those of the late

562 Paleozoic (DiMichele and Phillips, 1996; DiMichele et al., 2001; Hotton et al., 2001; Scheckler,

563 1986). That being said, even when the structural novelty is extensive, the attribution of any

564 particular environmental or ecophysiological impact to that novelty must be evaluated

565 critically—as with, for example, suggested feedbacks between angiosperm evolution and marine

566 productivity (Boyce and Lee, 2011) — and within the context of all available evidence. Similarly,

567 the structure of the arborescent lycopsids consists of a series of challenging novelties, but all of

568 these innovations are housed in plants limited to saturated substrates that likely were prone to

569 nutrient limitations and low productivity. There is no reason to expect that these trees were

570 immune to those stresses. Arborescent lycopsids require no special attention as an outlier in 
571 discussions over the role of vegetation and plant evolution in climate/biogeochemical cycling or

572 in arguments over the productivity of plants through time (Birgenheier et al., 2010; Cleal and

573 Thomas, 2005; Frank et al., 2008; González and Díaz Saravia, 2010; Greb, 2013; Horton et al.,

574 2012) and any calculations or models directly requiring such an expectation should be

575 reconsidered as suspect.

576 The plants of the Silurian through the Carboniferous may be composed almost

577 exclusively of lineages that either are now extinct or possess highly dissimilar modern members,

578 but they are all just plants and plants all operate under similar physical constraints. There should

579 be no expectation of anything shockingly different in these constraints during the early evolution

580 of terrestrial vegetation. A variety of evolutionary novelties, such as angiosperms, $\mathrm{C}_{4}$ grasses,

581 CAM succulents, epiphytes, and secondary aquatics, have indeed been transformative — as were

582 the parallel evolutions of leaves, roots, and secondary growth earlier in Earth history—but these

583 transformations involved expansion into less productive environments or increasing productivity

584 in the productive environments. Such advances would have been marginal compared to what has

585 been attributed to the arborescent lycopsids: the maximum differences in productivity through

586 time, when the fossil record is considered more broadly, are of the order of a factor of two or

587 three (Beerling and Woodward, 1997; Boyce and Zwieniecki, 2012; Brodribb et al., 2007;

588 Franks and Beerling, 2009), not twenty. When evaluating the biology of Paleozoic fossil plants

589 and the transitions to terrestrial environments, the physiological possibilities exhibited by the

590 diversity of living plants should be a guide. Direct and extraordinary evidence is needed for any

591 argument for a substantial expansion of that range.

592

593 


\section{Acknowledgments}

595 The authors thank T.L. Phillips, H.W. Pfefferkorn, R.M. Bateman, H. Kerp, and T.L. Rintoul for

596 helpful discussions on many of the matters covered in this paper, as well as three anonymous

597 reviewers; however, the authors bear sole responsibility for the ideas expressed here. This

598 research was supported by National Science Foundation Grant \#EAR1024041 (C.K.B).

\section{References}

601 Algeo, T.J., Scheckler, S.E., 1998. Terrestrial-marine teleconnections in the Devonian: links 602 between the evolution of land plants, weathering processes, and marine anoxic events.

603 Philosophical Transactions of the Royal Society of London B 353, 113-130.

604 Alroy, J., 1999. The fossil record of North American mammals: evidence for a Paleocene 605 evolutionary radiation. Systematic Biology 48, 107-118.

606 Andrews, H.N., Murdy, W.H., 1958. Lepidophloios--And ontogeny in arborescent lycopods.

607 American Journal of Botany 45, 552-560.

608 Armstrong, J., Armstrong, W., 2009. Record rates of pressurized gas-flow in the great horsetail,

609 Equisetum telmateia. Were Carboniferous Calamites similarly aerated? New Phytologist 184, 610 202-215.

611 Armstrong, J., Armstrong, W., Beckett, P.M., 1992. Phragmites australis: Venturi- and 612 humidity-induced pressure flows enhance rhizome aeration and rhizosphere oxidation. New 613 Phytologist 120, 197-207.

614 Armstrong, W., Brändle, R., Jackson, M.B., 1994. Mechanisms of flood tolerance in plants. Acta 615 Botanica Neerlandica 43, 307-358.

616 Baker, R.A., DiMichele, W.A., 1997. Biomass allocation in Late Pennsylvanian coal-swamp 617 plants. Palaios 12, 127-132.

618 Barber, D.A., 1961. Gas exchange between Equisetum limosum and its environment. Journal of 619 Experimental Botany 12, 243-251.

620 Bateman, R.M., 1994. Evolutionary - developmental change in the growth architecture of fossil 621 rhizomorphic lycopsids: scenarios constructed on cladistic foundations. Biological Reviews 69, $622 \quad 527-597$.

623 Bateman, R.M., DiMichele, W.A., Willard, D.A., 1991. Hizemodendron, gen. nov., a 624 pseudoherbaceous segregate of Lepidodendron (Pennsylvanian): phylogenetic context for 625 evolutionary changes in lycopsid growth architecture. Systematic Botany 16, 195-205.

626 Bateman, R.M., DiMichele, W.A., Willard, D.A., 1992. Experimental cladistic analysis of 627 anatomically preserved arborescent lycopsids from the Carboniferous of Euramerica: an essay on 628 paleobotanical phylogenetics. Annals of the Missouri Botanical Gardens 79, 500-559.

629 Bazzaz, F.A., Carlson, R.W., Harper, J.L., 1979. Contribution to reproductive effort by 630 photosynthesis of flowers and fruits. Nature 279, 554-555.

631 Beck, C.B., 1967. Eddya sullivanensis, gen. et sp. nov., a plant of gymnospermic morphology

632 from the Upper Devonian of New York. Palaeontographica Abt. B 121, 1-22. 
Beckett, P.M., Armstrong, W., Justin, S.H.F.W., Armstrong, J., 1988. On the relative importance of convective and diffusive gas flows in plant aeration. New Phytologist 110, 463-468. Beerling, D.J., Berner, R.A., 2000. Impact of a Permo-Carboniferous high O2 event on the terrestrial carbon cycle. Proceedings of the National Academy of Sciences USA 97, 12428-

Beerling, D.J., Lake, J.A., Berner, R.A., Hickey, L.J., Taylor, D.W., Royer, D.L., 2002. Carbon isotopic evidence implying high $\mathrm{O} 2 / \mathrm{CO} 2$ ratios in the Permo-Carboniferous atmosphere.

\section{Geochimica et Cosmochimica Acta 66, 3757-3767.}

Beerling, D.J., Woodward, F.I., 1997. Changes in land plant function over the Phanerozoic: reconstructions based on the fossil record. Botanical Journal of the Linnean Society 124, 137153.

Benton, M.J., 1998. The quality of the fossil record of the vertebrates, in: Donovan, S.K., Paul, C.R.C. (Eds.), The adequacy of the fossil record. New York: Wiley, 269-303.

Berner, R.A., 2003. The long-term carbon cycle, fossil fuels, and atmospheric composition. Nature 426, 323-326.

Berner, R.A., 2004. The Phanerozoic carbon cycle: $\mathrm{CO}_{2}$ and $\mathrm{O}_{2}$. Oxford: Oxford University Press.

Berner, R.A., 2006. GEOCARBSULF: A combined model for Phanerozoic atmospheric $\mathrm{O}_{2}$ and $\mathrm{CO}_{2}$. Geochimica et Cosmochimica Acta 70, 5653-5664.

Berner, R.A., Canfield, D.E., 1989. A new model for atmospheric oxygen over Phanerozoic time. American Journal of Science 289, 333-361.

Berner, R.A., Kothavala, Z., 2001. GEOCARB III: a revised model of atmospheric $\mathrm{CO}_{2}$ over Phanerozoic time. American Journal of Science 301, 182-204.

Bertrand, C.E., 1891. Remarques sur le Lepidodendron harcourtii de Witham. Mémoires de Facultés de Lille 2, 1-159.

Bierhorst, D.W., 1971. Morphology of vascular plants. New York: MacMillan.

Birgenheier, L.P., Frank, T.D., Fielding, C.R., Rygel, M.C., 2010. Coupled carbon isotopic and sedimentological records from the Permian system of eastern Australia reveal the response of atmospheric carbon dioxide to glacial growth and decay during the late Paleozoic Ice Age. Palaeogeography, Palaeoclimatology, Palaeoecology 286, 178-193.

Bomfleur, B., Pott, C., Kerp, H., 2011. Plant assemblages from the Shafer Peak Formation (Lower

Jurassic), north Victoria Land, Transantarctic Mountains. Antarctic Science 23, 188-208. Bowden, W.B., 1987. The biogeochemistry of nitrogen in freshwater wetlands. Biogeochemistry 4, 313-348.

Boyce, C.K., 2008. The fossil record of plant physiology and development-what leaves can tell us. Paleontological Society Papers 14, 133-146.

Boyce, C.K., Abrecht, M., Zhou, D., Gilbert, P.U.P.A., 2010a. X-ray photoelectron emission spectromicroscopic analysis of arborescent lycopsid cell wall composition and Carboniferous coal ball preservation. International Journal of Coal Geology 83, 146-153.

Boyce, C.K., Brodribb, T., Feild, T.S., Zwieniecki, M.A., 2009. Angiosperm leaf vein evolution was physiologically and environmentally transformative. Proceedings of the Royal Society of London B 276, 1771-1776.

Boyce, C.K., Knoll, A.H., 2002. Evolution of developmental potential and the multiple independent origins of leaves in Paleozoic vascular plants. Paleobiology 28, 70-100. 
Boyce, C.K., Lee, J.-E., 2011. Could land plant evolution have fed the marine revolution? .

679 Paleontological Research 15, 100-105.

680 Boyce, C.K., Lee, J.-E., Feild, T.S., Brodribb, T., Zwieniecki, M.A., 2010b. Angiosperms helped put the rain in the rainforests: The impact of plant physiological evolution on tropical

\section{Boyce, C.K., Zwieniecki, M.A., 2012. Leaf fossil record suggests limited influence of} atmospheric $\mathrm{CO}_{2}$ on terrestrial productivity prior to angiosperm evolution. Proceedings of the National Academy of Sciences 109, 10403-10408.

Brezinski, D.K., Cecil, C.B., Skema, V.W., 2010. Late Devonian glacigenic and associated facies from the central Appalachian Basin, eastern United States. Geological Society of America Bulletin 122, 265-281.

Brezinski, D.K., Cecil, C.B., Skema, V.W., Kertis, C.A., 2009. Evidence for long-term climate change in Upper Devonian strata of the central Appalachians. Palaeogeography, Palaeoclimatology, Palaeoecology 284, 315-325.

Brinson, M.M., Bradshaw, H.D., Holmes, R.N., Elkins, J.B., Jr., 1980. Litterfall, stemflow, and throughfall nutrient fluxes in an alluvial swamp forest. Ecology 61, 827-835.

Brodribb, T.J., Feild, T.S., 2010. Leaf hydraulic evolution led a surge in leaf photosynthetic capacity during early angiosperm diversification. Ecology Letters 13, 175-183. Brodribb, T.J., Feild, T.S., Jordan, G.J., 2007. Leaf maximum photosynthetic rate and venation are linked by hydraulics. Plant Physiology 144, 1890-1898.

Burr, F.A., Evert, R.F., 1973. Some aspects of seive-element structure and development in Selaginella kraussiana. Protoplasma 78, 81-97.

Calder, J.H., Gibling, M.R., Scott, A.C., Davies, S.J., Hebert, B.L., 2006. A fossil lycopsid forest succession in the classic Joggins section of Nova Scotia: paleoecology of a disturbance-prone Pennsylvanian wetland. Geological Society of America Special Papers 399, 169-195.

Chaloner, W.G., Meyer-Berthaud, B., 1983. Leaf and stem growth in the Lepidodendrales. Botanical Journal of the Linnean Society 86, 135-148.

Cichan, M.A., 1985. Vascular cambium and wood development in selected Carboniferous plants. I. Lepidodendrales. American Journal of Botany 72, 1163-1176.

Cichan, M.A., 1986. Conductance in the wood of selected Carboniferous plants. Paleobiology $12,302-310$.

Cleal, C.J., Thomas, B.A., 2005. Palaeozoic tropical rainforests and their effect on global climates: is the past the key to the present? Geobiology 3, 13-31.

Collinson, M.E., Scott, A.C., 1987. Implications of vegetational change through the geological record on models for coal-forming environments, in: Scott, A.C. (Ed.), Coal and coal-bearing strata: Recent advances Geological Society Special Publication, 67-85.

Collinson, M.E., Van Bergen, P.F., Scott, A.C., de Leeuw, J.W., 1994. The oil-generating potential of plants from coal and coal-bearing strata through time: a review with new evidence from Carboniferous plants, in: Scott, A.C., Fleet, A.J. (Eds.), Coal and coal-bearing strata as oilprone source rocks? Geological Society Special Publication, 31-70.

Crookall, R., 1925. On the fossil flora of the Bristol and Somerset Coalfield. Geological Magazine 62, 145-180.

Davies, N.S., Gibling, M.R., 2011. Evolution of fixed-channel alluvial plains in response to Carboniferous vegetation. Nature Geoscience 4, 629-633. 
Davies, N.S., Gibling, M.R., 2013. The sedimentary record of Carboniferous rivers: Continuing influence of land plant evolution on alluvial processes and Palaeozoic ecosystems. Earth-Science

Reviews 120, 40-79.

Davies, N.S., Gibling, M.R., Rygel, M.C., 2011. Alluvial facies evolution during the Palaeozoic greening of the continents: case studies, conceptual models and modern analogues. Sedimentology 58, 220-258.

Day, F.P., Jr., 1982. Litter decomposition rates in the seasonally flooded Great Dismal Swamp. Ecology 63, 670-678.

Diéguez, C., Meléndez, N., 2000. Early Cretaceous ferns from lacustrine limestones at Las Hoyas, Cuenca Province, Spain. Palaentology 43, 1113-1141. DiMichele, W.A., 1980. Paralycopodites Morey \& Morey, from the Carboniferous of Euramerica--a reassessment of generic affinities and evolution of "Lepidodendron" brevifolium Williamson. American Journal of Botany 67, 1466-1476.

DiMichele, W.A., 1983. Lepidodendron hickii and generic delimitation in Carboniferous lepidodendrid lycopods. Systematic Botany 8, 317-333.

DiMichele, W.A., Bateman, R.M., 1996. The rhizomorphic lycopsids: a case-study in paleobotanical classification. Systematic Botany 21, 535-552.

DiMichele, W.A., DeMaris, P.J., 1987. Structure and dynamics of a Pennsylvanian-age Lepidodendron forest: colonizers of a disturbed swamp habitat in the Herrin (No. 6) coal of Illinois. Palaios 2, 146-157. DiMichele, W.A., Elrick, S.D., Bateman, R.M., 2013. Growth habit of the late Paleozoic rhizomorphic tree-lycopsid family Diaphorodendraceae: Phylogenetic, evolutionary, and paleoecological significance. American Journal of Botany 100, 1604-1625.

DiMichele, W.A., Falcon-Lang, H.J., 2011. Pennsylvanian 'fossil forests' in growth position ( $\mathrm{T}^{0}$ assemblages): origin, taphonomic bias and palaeoecological insights. Journal of the Geological Society, London 168, 585-605.

DiMichele, W.A., Falcon-Lang, H.J., Nelson, W.J., Elrick, S.D., Ames, P.R., 2007. Ecological gradients within a Pennsylvanian mire forest. Geology 35, 415-418.

DiMichele, W.A., Nelson, W.J., Elrick, S.D., Ames, P.R., 2009. Catastrophically buried Middle Pennsylvanian Sigillaria and calamitean sphenopsids from Indiana, USA: What kind of vegetation was this? Palaios 24, 159-166.

DiMichele, W.A., Phillips, T.L., 1985. Arborescent lycopod reproduction and paleoecology in a coal-swamp environment of late Middle Pennsylvanian age (Herrin Coal, Illinois, USA). Review of Palaeobotany and Palynology 44, 1-26.

DiMichele, W.A., Phillips, T.L., 1994. Paleobotanical and paleoecological constraints on models of peat formation in the Late Carboniferous of Euramerica. Palaeogeography, Palaeoclimatology, Palaeoecology 106, 39-90.

DiMichele, W.A., Phillips, T.L., 1996. Clades, ecological amplitudes, and ecomorphs: phylogenetic effects and persistence of primitive plant communities in the Pennsylvanian-age tropical wetlands. Palaeogeography, Palaeoclimatology, Palaeoecology 127, 83-105.

DiMichele, W.A., Stein, W.E., Bateman, R.M., 2001. Ecological sorting of vascular plant classes during the Paleozoic evolutionary radiation, in: Allmon, W.D., Bottjer, D.J. (Eds.), Evolutionary Paleoecology. New York: Columbia University Press, 285-335.

Drezner, T.D., 2014. The keystone saguaro (Carnegiea gigantea, Cactaceae): a review of its ecology, associations, reproduction, limits, and demographics. Plant Ecology 215, 581-595. 
Eggert, D.A., 1961. The ontogeny of Carboniferous arborescent Lycopsida. Palaeontographica

768 Abt. B 108, 43-92.

769 Eggert, D.A., 1972. Petrified Stigmaria of sigillarian origin from North America. Review of

770 Palaeobotany and Palynology 14, 85-99.

771 Eggert, D.A., Kanemoto, N.Y., 1977. Stem phloem of a middle Pennsylvanian Lepidodendron.

772 Botanical Gazette 138, 102-111.

773 Frank, T.D., Birgenheier, L.P., Montañez, I.P., Fielding, C.R., Rygel, M.C., 2008. Late Paleozoic

774 climate dynamics revealed by comparison of ice-proximal stratigraphic and ice-distal isotopic

775

776

777

778

779

780

781

782

783

784

785

786

787

788

789

790

791

792

793

794

795

796

797

798

799

800

801

802

803

804

805

806

807

808

809

810

811 records. Geological Society of America Special Paper 441, 1-12.

Frankenberg, J.M., Eggert, D.A., 1969. Petrified Stigmaria from North America: Part I.

Stigmaria ficoides, the underground portion of Lepidodendraceae. Palaeontographica Abt. B 128, 1-47.

Franks, P.J., Beerling, D.J., 2009. $\mathrm{CO}_{2}$-forced evolution of plant gas exchange capacity and water-use efficiency over the Phanerozoic. Geobiology 7, 227-236.

Gastaldo, R.A., 1986. Implications on the paleoecology of autochthonous lycopods in clastic sedimentary environments in the Early Pennsylvanian of Alabama. Palaeogeography, Palaeoclimatology, Palaeoecology 53, 191-212.

Gastaldo, R.A., Stevanović-Walls, I.M., Ware, W.N., Greb, S.F., 2004. Community heterogeneity of Early Pennsylvanian peat mires. Geology 32, 693-696.

Gensel, P.G., Pigg, K.B., 2010. An arborescent lycopsid from the Lower Carboniferous Price Formation, southwestern Virginia, USA and the problem of species delimitation. International Journal of Coal Geology 83, 132-145.

Gibling, M.R., Davies, N.S., 2012. Palaeozoic landscapes shaped by plant evolution. Nature Geoscience 5, 99-105.

Glasspool, I.J., Scott, A.C., 2010. Phanerozoic concentrations of atmospheric oxygen reconstructed from sedimentary charcoal. Nature Geoscience 3, 627-630.

Goldenberg, F., 1855. Flora Saraepontana fossilis. Saarbrücken, Germany: Verlag der Neumann'schen Buchhandlung.

González, C.R., Díaz Saravia, P., 2010. Bimodal character of the Late Paleozoic glaciations in Argentina and bipolarity of climatic changes. Palaeogeography, Palaeoclimatology,

Palaeoecology 298, 101-111.

Graham, R., 1935. An anatomical study of the leaves of the Carboniferous arborescent lycopods. Annals of Botany 49, 587-608.

Greb, S.F., 2013. Coal more than a resource: Critical data for understanding a variety of earthscience concepts. International Journal of Coal Geology 118, 15-32.

Green, W.A., 2010. The function of the aerenchyma in arborescent lycopsids: evidence of an unfamiliar metabolic strategy. Proceedings of the Royal Society of London B 277, 2257-2267. Griffiths, H., Ong, B.L., Avadhani, P.N., Goh, C.J., 1989. Recycling of respiratory $\mathrm{CO}_{2}$ during Crassulacean acid metabolism: alleviation of photoinhibition in Pyrrosia piloselloides. Planta $179,115-122$.

Große, W., 1996. Pressurised ventilation in floating-leaved aquatic macrophytes. Aquatic Botany 54, 137-150.

Henderson, A., 2002. Evolution and ecology of palms. New York: New York Botanical Garden Press.

812454. 
813 Horton, D.E., Poulsen, C.J., Montañez, I.P., DiMichele, W.A., 2012. Eccentricity-paced late

814 Paleozoic climate change. Palaeogeography, Palaeoclimatology, Palaeoecology 331-332, 150-

815161.

816 Hotton, C., L., Hueber, F.M., Griffing, D.H., Bridge, J.S., 2001. Early terrestrial plant

817 environments: an example from the Emsian of Gaspé, Canada, in: Gensel, P.G., Edwards, D.

818 (Eds.), Plants invade the land: evolutionary and environmental perspectives. New York:

819 Columbia University Press, 179-212.

820 Jeffrey, E.C., Wetmore, R.H., 1926. On the occurrence of parichnos in certain conifers. Annals

821 of Botany 40, 799-811.

822 Keeley, J.E., 1987. The adaptive radiation of photosynthetic modes in the genus Isoetes

823 (Isoetaceae), in: Crawford, R.M.M. (Ed.), Plant Life in Aquatic and Amphibious Habitats, 113-

824128.

Keeley, J.E., 1998. CAM photosynthesis in submerged aquatic plants. Botanical Review 64, 121175.

Khan, A.G., 2004. Mycotrophy and its significance in wetland ecology and wetland management, in: Wong, M.H. (Ed.), Developments in Ecosystems Elsevier B. V., 95-114.

Kidston, R., 1884. VII.-On a specimen of Pecopteris (? polymorpha, Brongn.) in circinate vernation, with remarks on the genera Spiropteris and Rhizomopteris of Schimper. Journal of Natural History 13, 73-76.

Knoll, A.H., 1986. Patterns of change in plant communities through geological time, in: Diamond, J.M., Case, T. (Eds.), Community Ecology. New York: Harper and Row, 126-141. Kosanke, R.M., 1979. A long-leaved specimen of Lepidodendron. Geological Society of America Bulletin 90, 431-434.

Kozlowski, T.T., 2002. Physiological-ecological impacts of flooding on riparian forest ecosystems. Wetlands 22, 550-561.

Krings, M., Taylor, T.N., Taylor, E.L., Dotzler, N., Walker, C., 2011. Arbuscular mycorrhizallike fungi in Carboniferous arborescent lycopsids. New Phytologist 191, 311-314.

Kruatrachue, M., Evert, R.F., 1974. Structure and development of sieve elements in the leaf of Isoetes muricata. American Journal of Botany 61, 253-266.

848 McElwain, J.C., Chaloner, W.G., 1995. Stomatal density and index of fossil plants track Leary, R.L., Thomas, B.A., 1989. Lepidodendron aculeatum with attached foliage: evidence of stem morphology and fossilization processes. American Journal of Botany 76, 283-288.

852 cypress swamp in southern Illinois. Ecology 60, 1116-1124.

853 Nauertz, E.A., Zasada, J.C., 1999. Lycopodium: growth form, morphology, and sustainability of

854 a non-timber forest product, in: Duchesne, L.C. (Ed.), Forest communities in the third millennium: linking research, business, and policy toward a sustainable non-timber forest product sector, 110-115.

857 Niklas, K.J., 1998. The influence of gravity and wind on land plant evolution. Review of 858 Palaeobotany and Palynology 102, 1-14. 
Niklas, K.J., Tiffney, B.H., Knoll, A.H., 1985. Patterns in vascular plant diversification: an analysis at the species level, in: Valentine, J.W. (Ed.), Phanerozoic diversity patterns: Profiles in macroevolution. Princeton: Princeton University Press, 97-128. Odling-Smee, F.J., Laland, K.N., Feldman, M.W., 2003. Niche Construction: the Neglected Process in Evolution. Princeton University Press Monographs in Population Biology 37, 1-472. Opluštil, S., 2010. Contribution to knowledge on ontogenetic developmental stages of Lepidodendron mannabachense Presl, 1838. Bulletin of Geosciences 85, 303-316. Opluštil, S., Pšenička, J., Libertín, M., Bek, J., Dašková, J., Šimůnek, Z., Drábková, J., 2009. buried in volcanic ash, Radnice Basin (Czech Republic). Palaios 24, 726-746.

Page, S.E., Rieley, J.O., Shotyk, Ø.W., Weiss, D., 1999. Interdependence of peat and vegetation in a tropical peat swamp forest. Philosophical Transactions of the Royal Society B 354, 18851897.

Pezeshki, S.R., 2001. Wetland plant responses to soil flooding. Environmental and Experimental Botany 46, 299-312.

Phillips, T.L., 1979. Reproduction of heterosporous arborescent lycopods in the MississippianPennsylvanian of Euramerica. Review of Palaeobotany and Palynology 27, 239-289.

Phillips, T.L., DiMichele, W.A., 1992. Comparative ecology and life-history biology of arborescent lycopsids in Late Carboniferous swamps of Euramerica. Annals of the Missouri Botanical Gardens 79, 560-588.

Phillips, T.L., Peppers, R.A., DiMichele, W.A., 1985. Stratigraphic and interregional changes in Pennsylvanian coal-swamp vegetation: environmental inferences. International Journal of Coal Geology 5, 43-109.

Prinzing, A., 2001. The niche of higher plants: evidence for phylogenetic conservatism. Proceedings of the Royal Society B 268, 2383-2389.

Raven, J.A., 1970. Exogenous inorganic carbon sources in plant photosynthesis. Biological Reviews 45, 167-220.

Raven, J.A., 2009. Horsetails get the wind up. New Phytologist 184, 6-9.

Reich, P.B., Ellsworth, D.S., Walters, M.B., Vose, J.M., Gresham, C., Volin, J.C., Bowman, W.D., 1999. Generality of leaf trait relationships: A test across six biomes. Ecology 80, 19551969.

Reich, P.B., Koike, T., Gower, S.T., Schoettle, A.W., 1995. Causes and consequences of variation in conifer leaf life-span, in: Smith, W.K., Hinckley, T.M. (Eds.), Ecophysiology of coniferous forests. San Diego: Academic Press, 225-254.

Rex, G.M., 1983. The compression state of preservation of Carboniferous lepidodendrid leaves. Review of Palaeobotany and Palynology 39, 65-85.

Romberger, J.A., Hejnowicz, Z., Hill, J.F., 1993. Plant structure: function and development. A treatise on anatomy and vegetative development with special reference to woody plants. Berlin: Springer-Verlag. Rothwell, G.W., 1984. The apex of Stigmaria (Lycopsida), rooting organ of Lepidodendrales. American Journal of Botany 71, 1031-1034.

Rothwell, G.W., Wyatt, S.E., Tomescu, A.M.F., 2014. Plant evolution at the interface of paleontology and developmental biology: An organism-centered paradigm. American Journal of Botany 101, 899-913.

Royer, D.L., Berner, R.A., Montañez, I.P., Tabor, N.J., Beerling, D.J., 2004. $\mathrm{CO}_{2}$ as a primary driver of Phanerozoic climate. GSA Today 14, 4-10. 
Sabine, C.L., Feely, R.A., Gruber, N., Key, R.M., Lee, K., Bullister, J.L., Wanninkhof, R., Wong, C.S., Wallace, D.W.R., Tilbrook, B., Millero, F.J., Peng, T.-H., Kozyr, A., Ono, T., Rios, A.F., 2004. The oceanic sink for anthropogenic CO2. Science 305, 367-371.

908 Sanders, H., Rothwell, G.W., Wyatt, S., 2007. Paleontological context for the developmental mechanisms of evolution International Journal of Plant Science 168, 719-728. Scheckler, S.E., 1986. Geology, floristics, and paleoecology of Late Devonian coal swamps from Appalachian North America. Annales de la Société Géologique de Belgique 109, 209-222. Scheffer, M., Carpenter, S.R., 2003. Catastrophic regime shifts in ecosystems: linking theory to observation. Trends in Ecology and Evolution 18, 648-656.

Schlesinger, W.H., 1978. Community structure, dynamics and nutrient cycling in the Okefenokee cypress swamp-forest. Ecological Monographs 48, 43-65.

Sepkoski, J.J., Jr., 1981. A factor analytic description of the Phanerozoic marine fossil record. Paleobiology 7, 36-53.

Smith, S.E., Read, D.J., 1997. Mycorrhizal symbiosis, 2nd ed. San Diego: Academic Press. Speck, T.S., 1994. A biomechanical method to distinguish between self-supporting and non selfsupporting fossil plants. Review of Palaeobotany and Palynology 81, 65-82.

Stewart, W.N., 1947. A comparative study of stigmarian appendages and Isoetes roots. American Journal of Botany 34, 315-324.

Talbot, R.J., Etherington, J.R., Bryant, J.A., 1987. Comparative studies of plant growth and distribution in relation to waterlogging. XII. Growth, photosynthetic capacity and metal ion uptake in Salix caprea and S. cinerea ssp. oleifolia. New Phytologist 105, 563-574.

Taylor, T.N., Taylor, E.L., Krings, M., 2009. Paleobotany: the biology and evolution of fossil plants, Second ed. Burlington, MA: Academic Press.

Thomas, B.A., 1970. Epidermal studies in the interpretation of Lepidodendron species. Palaeontology 13, 145-173.

Thomas, B.A., 1972. Growth changes in Sigillaria latibasa. Annals of Botany 36, 1023-1027. Thomas, B.A., Seyfulla, L.J., 2015. Stigmaria Brongniart: a new specimen from Duckmantian (Lower Pennsylvanian) Brymbo (Wrexham, North Wales) together with a review of known casts and how they were preserved. Geological Magazine 152, 858-870.

Thomas, B.A., Watson, J., 1976. A rediscovered 114 - foot Lepidodendron from Bolton, Lancashire. Geological Journal 11, 15-20.

Thomas, B.A., Zodrow, E.L., Cleal, C.J., 2010. Leafy branches of Bothrodendron punctatum from the Westphalian D (Asturian) of Nova Scotia, Canada. Atlantic Geology 46, 1-6.

Toffa, T., 2004. Cape Town | Bo-Kaap - the architecture of identity, in: Malan, A. (Ed.), Studies and debates in vernacular architecture in the western Cape. Durbanville, South Africa: Vernacular Architecture Society of South Africa, 16-35.

Tomlinson, P.B., 2006. The uniqueness of palms. Botanical Journal of the Linnean Society 151, 5-14.

Tomlinson, P.B., Huggett, B.A., 2012. Cell longevity and sustain primary growth in palm stems. American Journal of Botany 99, 1891-1902.

Uhl, N.W., Dransfield, J., 1987. Genera Palmarum. Lawrence, Kansas: Allen Press.

Vogel, S., 1994. Life in moving fluids: the philosophical biology of flow, 2nd ed Princeton University Press.

Vogel, S., 2012. The life of a leaf. Chicago: University of Chicago Press.

Walters, E., 1891. Mammoth Sigillaria. Kansas City Scientist 5, 140-142. 
Wang, S.-J., Tian, B.-L., Chen, G.-R., 2002. Anatomically preserved lepidodendralean plants from Permian coal balls of China: leaves of Lepidophylloides snigirevskaya. Review of

952 Palaeobotany and Palynology 122, 63-76.

953 Warmbrodt, R.D., Evert, R.F., 1974. Structure and development of the sieve element in the stem of Lycopodium lucidulum. American Journal of Botany 61, 267-277. Webb, C.O., Ackerly, D.D., McPeek, M.A., Donoghue, M.J., 2002. Phylogenies and community ecology. Annual Review of Ecology and Systematics 33, 475-505. Wiens, J.J., Ackerly, D.D., Allen, A.P., Anacker, B.L., Buckley, L.B., Cornell, H.V., Damschen, E.J., Davies, T.J., Grytnes, J.-A., Harrison, S.P., Hawkins, B.A., Holt, R.D., McCain, C.M., Stephens, P.R., 2010. Niche conservatism as an emerging principle in ecology and conservation biology. Ecology Letters 13, 1310-1324.

Willard, D.A., Phillips, T.L., 1993. Paleobotany and palynology of the Bristol Hill Coal Member (Bond Formation) and Friendsville Coal Member (Mattoon Formation) of the Illinois Basin (Upper Pennsylvanian). Palaios 8, 574-586.

Williamson, W.C., 1872. On the organization of the fossil plants of the Coal-Measures. Part II. Lycopodiaceae: Lepidodendra and Sigillariae. Philosophical Transactions of the Royal Society of London 162, 197-240.

Williamson, W.C., 1887. A monograph on the morphology and histology of Stigmaria ficoides. London: The Palaeontographical Society.

Wnuk, C., 1985. The ontogeny and paleoecology of Lepidodendron rimosum and Lepidodendron bretonense trees from the Middle Pennsylvanian of the Bernice Basin (Sullivan County, Pennsylvania, U.S.A.). . Palaeontographica, Abteilung B 195, 153-181.

Wnuk, C., 1989. Ontogeny and paleoecology of the Middle Pennsylvanian arborescent lycopod Bothrodendron punctatum, Bothrodendraceae (western Middle Anthracite field, Shamokin quadrangle, Pennsylvania). American Journal of Botany 76, 966-980.

Wright, I.J., Reich, P.B., Westoby, M., Ackerly, D.D., Baruch, Z., Bongers, F., Cavender-Bares, J., Chapin, T., Cornelissen, J.H.C., Diemer, M., Flexas, J., Garnier, E., Groom, P.K., Gulias, J., Hikosaka, K., Lamont, B.B., Lee, T., Lee, W., Lusk, C., Midgley, J.J., Navas, M.-L., Niinemets, Ü., Oleksyn, J., Osada, N., Poorter, H., Poot, P., Prior, L., Pyankov, V.I., Roumet, C., Thomas, S.C., Tjoelker, M.G., Veneklaas, E.J., Villar, R., 2004. The worldwide leaf economics spectrum. Nature 428, 821-827.

Wright, I.J., Westoby, M., 2002. Leaves at low versus high rainfall: coordination of structure, lifespan and physiology. New Phytologist 155, 403-416.

Zwieniecki, M.A., Boyce, C.K., 2014. Evolution of a unique anatomical precision in angiosperm leaf venation lifts constraints on vascular plant ecology. Proceedings of the Royal Society B 281,

986 20132829. 


\section{Figure Captions}

988 Figure 1. Reconstructions of major arborescent lycopsid trees. Left to right, Diaphorodendron 989 scleroticum, Lepidophloios hallii, Paralycopodites brevifolius, Synchysidendron sp. (note, later 990 research has altered this reconstruction, see DiMichele et al., 2013), Sigillaria sp.,

991 Diaphorodendron vasculare, Lepidodendron sp. From Bateman et al., 1992, used with

992 permission of the Missouri Botanical Garden. Mary Parrish, Smithsonian Institution, artist. 993

994 Figure 2. Lycopsid vegetative structure. A. Diaphorodendron vasculare, stem base cross section. 995 Wood cylinder (W) is small but highly efficient at water conduction. Note the small primary 996 xylem cylinder. There is no secondary phloem. Secondary cortex/periderm, the main support of 997 the stem, is thick, and somewhat collapsed and compressed. Murphysboro Coal, Middle 998 Pennsylvanian, Indiana. USNM specimen 458251 (cellulose acetate peel of coal ball in the 999 collections of the University of Illinois). From (DiMichele and Phillips, 1994), used with

1000 permission of Elsevier. B. Trunk of Lepidodendron sp. with leaf cushions surrounding the entire 1001 girth of the stem. Field Museum of Natural History specimens PP52325 and PP52326. Top scale

1002 bar increments in centimeters. C. Stigmaria ficoides main axis with attached lateral rootlets.

1003 Underclay beneath the "Cottage coal", a presently informal name used for a coal bed above the 1004 Middle Pennsylvanian Baker Coal, Desmoinesian age, Illinois.

1005

1006 Figure 3. Aerenchyma forming potential of lycopsid tissues. A. Cross-section of

1007 Diaphorodendron vasculare deciduous lateral branch of aerial axis showing prominent cortical

1008 cavity between central wood and peripheral periderm, although it is unclear how much cortical

1009 decay is pre-versus post-mortem. As part of a peat substrate, the air cavities in this stem were 
1010 subsequently filled with the stigmarian rootlets of a later tree. The rootlet cross-sections, which

1011 are thin walled and preserved more faintly than the Diaphorodendron axis, are also distinctly

1012 aerenchymatous. From the Cayuga locality of the Murphysboro Coal, Indiana. B.

1013 Lepidodendron hickii longitudinal section of leaf cushion showing external connectivity of 1014 parichnos aerenchyma system. $\mathrm{LS}=$ leaf scar, $\mathrm{LGP}=$ ligule pit, $\mathrm{LT}=$ leaf trace, $\mathrm{PAR}=$ 1015 parichnos, IFP = infrafoliar parichnos. Redrawn from (DiMichele, 1983).

1016

1017 Figure 4. The opposite ends of the tree lycopsid growth trajectory. A. Longitudinal section 1018 through an embryonic arborescent lycopsid of Lepidophloios $\mathrm{sp} . \mathrm{s}=$ shoot, $\mathrm{r}=$ root. B. Cross 1019 section through and embryo of Lepidophloios sp., $\mathrm{s}=$ shoot, $\mathrm{r}=$ root, note the primary xylem 1020 present in the shoot and lacking in the root, and secondary xylem in both. C. Lycopsid tree 1021 stump formed following tree death, USNM specimen 34989. Scale bar is 12 inches. (A, B from 1022 (Rothwell et al., 2014), used with permission of the Botanical Society of America) 1023

1024 Figure 5. Palm Tree Mosque, Cape Town, South Africa--Longest documented lifespan of a palm 1025 (taxon indeterminate). A. 1840, drawing by N. Gertse, as reprinted by Toffa (2006). The two 1026 large trees would date at least to the founding of the mosque in 1807 and may be older than the 1027 building itself, constructed in 1788 , based on their sizes and growth rates over the subsequent 1028200 years. B. 1915, photo by A. Elliot. C. 1988, photo by J. Szymanowski. The shorter tree is a 10291966 replacement of one of the original two trees. D. 2012, photo by Discott. The only tree 1030 remaining is the 1966 replacement (of a different, faster growing species than the original trees). 1031 A photo (not shown) on display inside the mosque shows both original trees in 1876 with heights 1032 appropriately intermediate between the 1840 drawing and 1915 photo. With the tree now dead 
1033 (by 2008, based on other photos), species identification is not available. [All images available in

1034 the public domain or via Wikimedia Commons (http://commons.wikimedia.org).]

1035

1036 Figure 6. The leaves of arborescent lycopsids. A. Outline cross-sections of various kinds of 1037 Lepidophylloides. Dotted area represents thick-walled fibrous cells; solid black area represents 1038 xylem; hatched area represents transfusion tissue. Magnifications vary, but note relative leaf 1039 thickness, peripheral sclerenchyma, and the relatively small area dedicated to vasculature. B.

1040 Anatomical cross section of Lepidophylloides taiyuanensis somewhat distorted by compression.

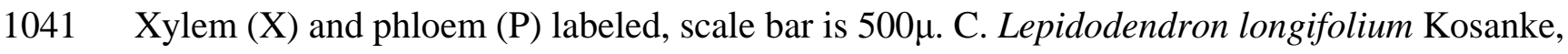

1042 type specimen on display at the Illinois State Geological Survey. Note long leaves in attachment

1043 to the stem. The leaf cushions are exposed along the fracture plane of the rock in which the plant

1044 specimen is preserved. (A, B from (Wang et al., 2002), used with permission of Elsevier)

1045

1046 Figure 7. Growth stages of arborescent lycopsids. A. Small, possibly juvenile plant attributed to

1047 Sigillaria by Goldenberg, (1855). B. Hypothetical reconstruction of a monocarpic lycopsid prior

1048 to crown formation with a thick, columnar trunk (From Andrews and Murdy, 1958, used with

1049 permission of the Botanical Society of America). C. Lower crown branches of Lepidodendron

1050 mannabachense. USNM specimen 528667.

1051

1052 Figure 8. Polycarpic arborescent lycopsid remains. A. Paralycopodites sp. main trunk with 1053 small, deciduous lateral branch scars, vertically disposed. Arrows point to attached leaves.

1054 Lower Pennsylvanian, Alabama, John Cooke Collection, USNM. B. Diaphorodendron sp.

1055 fragment of deciduous lateral branch system with leaves still in attachment (leaves are usually 
1056 not found in attachment in this genus). Middle Pennsylvanian, Springfield coal, Indiana. C.

1057 Synchysidendron sp., main trunk with clearly marked deciduous lateral branch scars and still 1058 attached leaf cushions. On lower portions of this large trunk, of which this is the most distal 1059 portion, the leaf bases are not present, even though trunk diameter is approximately the same 1060 along the entire preserved length (see DiMichele et al., 2013, in which the full specimen is 1061 illustrated). USNM specimen 7304. Middle Pennslvanian, Illinois. Scale bar is 18 inches. 1062 